\title{
Pengaruh Jenis dan Tingkat Kerapatan Gulma Terhadap Pertumbuhan dan Produksi Tanaman Sorgum (Sorghum Bicolor L.)
}

\section{Effect of Type and Density of Weeds on The Growth and Production of Sorghum (Sorgum Bicolor L.)}

\author{
Dita Anggeraini ${ }^{1}$, Dad R.J. Sembodo ${ }^{2}$, Sunyoto $^{2}$ \\ ${ }^{1}$ Mahasiswa Jurusan Agroteknologi FP, Unila \\ ${ }^{2}$ Jurusan Agroteknologi FP, Unila \\ Jln. Prof. Soemantri Brojonegoro, No. 1 Bandar Lampung 35145 \\ Email: dita_anggeraini@ymail.com
}

\begin{abstract}
Sorghum is one of serealia plants that have a big potential to be developed. Sorghum is beneficial as a source of food, animal feed, as well as various industrial raw materials. Sorghum is potential to be developed with the application of proper cultivation, one of them is optimal maintenance. The lack of maintenance cause low production. One of maintenance is weed control. Weeds can create a competition with cultivation plants to fight means growing. Type and weed density are influence growth a development of sorghum. The purpose of this research is to know: (1) The influence of type of weeds to growth and production of sorghum plants, (2) The influence of weeds density to growth and production of sorghum plant, and (3) There is interaction between type and weeds density when influence the growth of weeds, also growth and production of sorghum plants. This research is done in South Lampung and weeds laboratory University of Lampung on December 2014 April 2015. Treatments arranged in a factorial strip plot design with three replications. The first factor is three types of weeds, that are Asystasia gangetica, Cyperus rotundus, and Rottboelia exaltata. The second factor is density 0, 10, 20, 40, and 80 weeds $/ \mathrm{m}^{2}$. If assumption are met, the data is analyzed by using variance analysis and followed by a least significant difference (LSD) 5\%. The result shows: (1) The type of weeds influence growth and yield component of plant height and steam diameter 3 WAP, fresh weight and dry stover, also weight of 100 grains on water content) WC14\%, (2) The density of 80 weeds $/ \mathrm{m}^{2}$ influence the height a plant 3 and 9 WAP, number of leaves 6 MST, steam diameter 3, 6, and 9 WAP, weight of fresh stover plant, weight of 100 grains on water content $14 \%$, weight of sorghum seed, and (3) There is no interaction between the type and weeds density when influence growth and sorghum production, but there is interaction when influence the growth of weeds.
\end{abstract}

Keyword: sorghum, weeds, competition

Diterima: 15 Oktober 2015, disetujui 19 Desember 2015

\section{PENDAHULUAN}

Sorgum merupakan salah satu jenis tanaman serealia yang mempunyai potensi besar untuk dikembangkan di Indonesia karena mempunyai daerah adaptasi yang luas. Tanaman sorgum mempunyai 

ketahanan tumbuh lebih baik dibanding tanaman serealia lain di lahan kering dengan iklim kering, daya adaptasi agroekologi yang luas, tahan terhadap kekeringan, produksi tinggi, perlu input lebih sedikit serta lebih tahan terhadap hama dan penyakit (Sumarno dan Karsono 1996 dalam Lindung, 2011). Sorgum berguna sebagai sumber bahan pangan, pakan ternak, maupun bahan baku bermacam industri. Sorgum berpotensi baik untuk dikembangkan dengan penerapan teknologi budidaya yang tepat seperti penggunaan varietas unggul, pemupukan yang tepat, serta pemeliharaan yang optimal. Pemeliharaan tanaman yang kurang optimal akan mengakibatkan rendahnya produksi tanaman sorgum. Pemeliharaan tanaman salah satunya yaitu pengendalian gulma.

Adanya gulma dapat menimbulkan persaingan antara tanaman dengan gulma. Persaingan antara gulma dan tanaman mengakibatkan perebutan unsur hara, air, dan cahaya matahari dan menimbulkan kerugian dalam produksi baik kualitas maupun kuantitas. Faktor-faktor yang menentukan tingkat kompetisi gulma adalah jenis gulma, kerapatan gulma, waktu kehadiran gulma, allelokimia, dan kultur teknis yang diterapkan (Sembodo, 2010). Kerapatan gulma sangat berpengaruh terhadap pertumbuhan tanaman budidaya. Semakin rapat gulma, persaingan yang terjadi antara gulma dan tanaman pokok semakin hebat, pertumbuhan tanaman pokok semakin terhambat, dan hasilnya semakin menurun (Moenandir, 1993).

Penelitian ini bertujuan untuk mengetahui: (1) pengaruh jenis gulma terhadap pertumbuhan dan produksi tanaman sorgum, (2) pengaruh kerapatan gulma terhadap pertumbuhan dan produksi tanaman sorgum, dan (3) adanya interaksi antara jenis dan kerapatan gulma dalam mempengaruhi pertumbuhan gulma, serta pertumbuhan dan produksi tanaman sorgum.

\section{METODE}

Penelitian ini dilaksanakan di Desa Haji Mena, Kecamatan Natar, Kabupaten Lampung Selatan dan Laboratorium Gulma Fakultas Pertanian Universitas Lampung, mulai bulan November 2014 sampai April 2015. Alat yang jangka sorong, tugal dan meteran. Bahan yang digunakan yaitu benih sorgum varietas Numbu, bibit gulma Asystasia gangetica, Cyperus rotundus, Rottboelia exaltata, pupuk urea, KCl, dan SP36.

Perlakuan disusun secara faktorial dalam Rancangan Petak Berjalur (Strip Plot) dengan 3 ulangan. Lahan diolah dengan pembajakan dua minggu sebelum tanam. Petak penelitian sebanyak 45 petak perlakuan yang masing-masing petak perlakuan $1,5 \mathrm{~m}$ x $2 \mathrm{~m}$ dan jarak antar petak 0,5 $\mathrm{m}$. Penanaman benih sorgum dilakukan dengan cara ditugal dengan jarak tanam $80 \mathrm{~cm}$ x $20 \mathrm{~cm}$. Penanaman gulma dilakukan pada saat 1 MST setelah penanaman sorgum. Pemupukan pertama $50 \mathrm{~kg} / \mathrm{ha}$ urea, $100 \mathrm{~kg} / \mathrm{ha} \mathrm{KCl}$, dan 150 $\mathrm{kg} / \mathrm{ha}$ SP-36 yang diberikan pada umur 2 minggu setelah tanam (mst) dan $50 \mathrm{~kg} / \mathrm{ha}$ pupuk Urea diberikan pada saat tanaman berumur 6 MST.

Variabel pengamatan dalam penelitian ini meliputi pertumbuhan gulma, pertumbuhan tanaman, dan komponen hasil tanaman. Pengamatan terhadap pertumbuhan gulma antara lain: pengamatan persentase penutupan gulma secara visual pada 3, 6, dan 9 MST dan bobot kering gulma pada 9 MST. Pengamatan terhadap pertumbuhan tanaman antara lain: tinggi tanaman, jumlah daun, diameter batang dari 4 tanaman sampel pada 3, 6, dan 9 MST, bobot brangkasan basah dan kering tanaman sorgum. Pengamatan terhadap komponen hasil tanaman dilakukan saat panen sorgum pada 14 MST, pengamatan tersebut antara lain: panjang malai, bobot 100 butir, bobot biji per malai, serta produksi sorgum pada KA 14\% pada petak panen 2,25 $\mathrm{m}^{2}$. Homogenitas diuji dengan uji Bartlett dan aditivitas data diuji dengan uji Tukey. Bila asumsi terpenuhi, data dianalisis ragam dan dilanjutkan dengan uji beda nyata terkecil (BNT) pada taraf 5\%. 


\section{HASIL DAN PEMBAHASAN}

\section{Pertumbuhan Gulma}

Hasil penelitian menunjukkan bahwa jenis dan kerapatan saling berinteraksi dalam mempengaruhi persentase penutupan gulma pada 3 MST (Tabel 1). Asystasia gangetica, Cyperus rotundus, dan Rottboelia exaltata menghasilkan penutupan gulma yang sama pada kerapatan 10,40 , dan $80 \mathrm{gulma} / \mathrm{m}^{2}$. Cyperus rotundus menghasilkan persentase penutupan terendah dibandingkan dengan Asystasia gangetica, dan Rottboelia exaltata pada kerapatan $20 \mathrm{gulma} / \mathrm{m}^{2}$. Semakin tinggi tingkat kerapatan maka semakin tinggi pula persentase penutupan gulma.

Tabel 1. Pengaruh jenis dan tingkat kerapatan gulma pada penutupan gulma 3 MST.

\begin{tabular}{|c|c|c|c|c|c|c|c|}
\hline \multirow{3}{*}{$\begin{array}{l}\text { Kerapatan } \\
\text { gulma } / \mathrm{m}^{2}\end{array}$} & \multicolumn{6}{|c|}{ Jenis gulma } & \multirow{3}{*}{$\begin{array}{l}\text { BNT } \\
0,05\end{array}$} \\
\hline & \multicolumn{2}{|c|}{ Asystasia gangetica } & \multicolumn{2}{|c|}{ Cyperus rotundus } & \multicolumn{2}{|c|}{ Rottboelia exaltata } & \\
\hline & ron & $\begin{array}{c}\text { Transformasi } \\
\sqrt{ } \sqrt{ } \sqrt{ }(x+0,5)\end{array}$ & ron & $\begin{array}{c}\text { Transformasi } \\
\sqrt{ } \sqrt{ } \sqrt{ }(x+0,5)\end{array}$ & ron & $\begin{array}{c}\text { Transformasi } \\
\sqrt{ } \sqrt{ } \sqrt{ }(\mathrm{x}+0,5)\end{array}$ & \\
\hline & \multicolumn{6}{|c|}{ 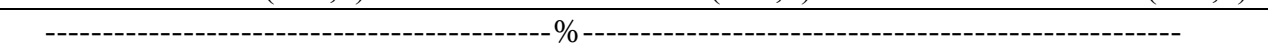 } & \multirow{7}{*}{$\mathbf{0 , 0 2 4}$} \\
\hline 0 & 0 & $\begin{array}{l}0,92 \mathrm{e} \\
\text { (a) }\end{array}$ & 0 & $\begin{array}{l}0,92 \mathrm{e} \\
\text { (a) }\end{array}$ & 0 & $\begin{array}{l}0,92 \mathrm{e} \\
\text { (a) }\end{array}$ & \\
\hline 10 & 7,00 & $\begin{array}{c}1,28 \mathrm{~d} \\
\text { (a) }\end{array}$ & 6,00 & $\begin{array}{l}1,26 \mathrm{~d} \\
\text { (a) }\end{array}$ & 7,00 & $\begin{array}{l}1,28 \mathrm{~d} \\
\text { (a) }\end{array}$ & \\
\hline 20 & 14,33 & $\begin{array}{c}1,40 \mathrm{c} \\
\text { (a) }\end{array}$ & 10,33 & $\begin{array}{c}1,34 \mathrm{c} \\
\text { (b) }\end{array}$ & 14,33 & $\begin{array}{c}1,40 \mathrm{c} \\
\text { (a) }\end{array}$ & \\
\hline 40 & 25,33 & $\begin{array}{c}1,50 \mathrm{~b} \\
\text { (a) }\end{array}$ & 21,67 & $\begin{array}{c}1,47 \mathrm{~b} \\
\text { (a) }\end{array}$ & 25,33 & $\begin{array}{l}1,50 \mathrm{~b} \\
\text { (a) }\end{array}$ & \\
\hline 80 & 50,00 & $\begin{array}{c}1,63 \mathrm{a} \\
\text { (a) }\end{array}$ & 44,67 & $\begin{array}{c}1,61 \mathrm{a} \\
\text { (a) }\end{array}$ & 50,00 & $\begin{array}{l}1,63 \mathrm{a} \\
\text { (a) }\end{array}$ & \\
\hline BNT 0,05 & & & & $\mathbf{0 , 0 2 3}$ & & & \\
\hline
\end{tabular}

Keterangan: Angka yang diikuti oleh huruf yang sama tidak berbeda nyata berdasarkan uji BNT pada taraf 5\% dengan tanda kurung untuk jenis gulma dan tanpa tanda kurung untuk kerapatan gulma.

Tabel 2. Pengaruh jenis dan tingkat kerapatan gulma pada penutupan gulma 6 MST

\begin{tabular}{|c|c|c|c|c|c|c|c|}
\hline \multirow{3}{*}{$\begin{array}{l}\text { Kerapatan } \\
\text { gulma } / \mathrm{m}^{2}\end{array}$} & \multicolumn{6}{|c|}{ Jenis gulma } & \multirow{3}{*}{$\begin{array}{l}\text { BNT } \\
0,05\end{array}$} \\
\hline & \multicolumn{2}{|c|}{ Asystasia gangetica } & \multicolumn{2}{|c|}{ Cyperus rotundus } & \multicolumn{2}{|c|}{ Rottboelia exaltata } & \\
\hline & Asli & $\begin{array}{c}\text { Transformasi } \\
\sqrt{ } \sqrt{ } \sqrt{ }(x+0,5)\end{array}$ & Asli & $\begin{array}{c}\text { Transformasi } \\
\sqrt{ } \sqrt{ } \sqrt{ }(x+0,5)\end{array}$ & Asli & $\begin{array}{c}\text { Transformasi } \\
\sqrt{ } \sqrt{ } \sqrt{ }(x+0,5)\end{array}$ & \\
\hline \multicolumn{7}{|c|}{ 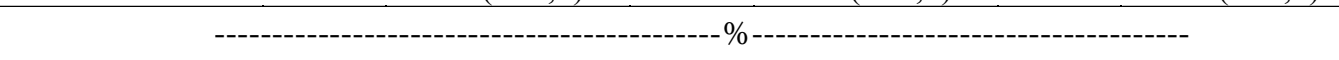 } & \multirow{6}{*}{$\mathbf{0 , 0 3}$} \\
\hline 0 & 0 & $\begin{array}{l}0,91 \mathrm{e} \\
\text { (a) }\end{array}$ & 0 & $\begin{array}{l}0,91 \mathrm{e} \\
\text { (a) }\end{array}$ & 0 & $\begin{array}{l}0,91 \mathrm{~d} \\
\text { (a) }\end{array}$ & \\
\hline 10 & 9,67 & $\begin{array}{l}1,33 \mathrm{~d} \\
\text { (b) }\end{array}$ & 8,67 & $\begin{array}{l}1,31 \mathrm{~d} \\
\text { (b) }\end{array}$ & 14,67 & $\begin{array}{l}1,40 \mathrm{c} \\
\text { (a) }\end{array}$ & \\
\hline 20 & 16,00 & $\begin{array}{l}1,41 \mathrm{c} \\
\text { (a) }\end{array}$ & 13,67 & $\begin{array}{c}1,39 \mathrm{c} \\
\text { (a) }\end{array}$ & 16,33 & $\begin{array}{l}1,42 \mathrm{c} \\
\text { (a) }\end{array}$ & \\
\hline 40 & 33,67 & $\begin{array}{l}1,55 \mathrm{~b} \\
\text { (a) }\end{array}$ & 26,00 & $\begin{array}{l}1,50 \mathrm{~b} \\
\text { (b) }\end{array}$ & 34,33 & $\begin{array}{l}1,55 \mathrm{~b} \\
\text { (a) }\end{array}$ & \\
\hline 80 & 82,00 & $\begin{array}{c}1,73 \mathrm{a} \\
\text { (a) }\end{array}$ & 77,33 & $\begin{array}{c}1,72 \mathrm{a} \\
\text { (a) }\end{array}$ & 88,00 & $\begin{array}{l}1,75 \mathrm{a} \\
\text { (a) }\end{array}$ & \\
\hline
\end{tabular}

BNT 0,05

0,035

Keterangan: Angka yang diikuti oleh huruf yang sama tidak berbeda nyata berdasarkan uji BNT pada taraf 5\% dengan tanda kurung untuk jenis gulma dan tanpa tanda kurung untuk kerapatan gulma 
Berdasarkan Tabel 2, jenis dan kerapatan gulma saling berinteraksi dalam mempengaruhi persentase penutupan gulma 6 MST. Rottboelia exaltata memiliki persentase penutupan tertinggi pada kerapatan 10 gulma $/ \mathrm{m}^{2}$. Cyperus rotundus menghasilkan persentase penutupan terendah pada kerapatan $40 \mathrm{gulma} / \mathrm{m}^{2}$ dibandingkan Asystasia gangetica dan Rottboelia exaltata. Pada kerapatan 10 dan $20 \mathrm{gulma} / \mathrm{m}^{2}$ perlakuan Rottboelia exaltata persentase penutupan yang dihasilkan sama. Menurut Hasanuddin, Erida, dan Safmaneli (2012) menyatakan bahwa tingkat kerapatan gulma yang tinggi akan berkurang secara alami seiring bertambahnya waktu karena terjadi persaingan antar tanaman.

Tabel 3. Pengaruh jenis dan tingkat kerapatan gulma pada penutupan gulma 9 MST

\begin{tabular}{|c|c|c|c|c|c|c|c|}
\hline \multirow{3}{*}{$\begin{array}{l}\text { Kerapatan } \\
\text { gulma/m }{ }^{2}\end{array}$} & \multicolumn{6}{|c|}{ Jenis gulma } & \multirow{3}{*}{$\begin{array}{l}\text { BNT } \\
0,05\end{array}$} \\
\hline & \multicolumn{2}{|c|}{ Asystasia gangetica } & \multicolumn{2}{|c|}{ Cyperus rotundus } & \multicolumn{2}{|c|}{ Rottboelia exaltata } & \\
\hline & non & $\begin{array}{c}\text { Transformasi } \\
\sqrt{ } \sqrt{ } \sqrt{ }(x+0,5)\end{array}$ & Ron & $\begin{array}{c}\text { Transformasi } \\
\sqrt{ } \sqrt{ } \sqrt{ }(x+0,5)\end{array}$ & Ron & $\begin{array}{c}\text { Transformasi } \\
\sqrt{ } \sqrt{ } \sqrt{ }(x+0,5)\end{array}$ & \\
\hline & ----- & --------- & -------- & -------- & - & -------- & \\
\hline 0 & 0 & $\begin{array}{l}0,91 \mathrm{e} \\
\text { (a) }\end{array}$ & 0 & $\begin{array}{l}0,91 \mathrm{e} \\
\text { (a) }\end{array}$ & 0 & $\begin{array}{l}0,91 \mathrm{e} \\
\text { (a) }\end{array}$ & \\
\hline 10 & 18,33 & $\begin{array}{l}1,44 \mathrm{~d} \\
\text { (a) }\end{array}$ & 15,67 & $\begin{array}{c}1,41 \mathrm{~d} \\
\text { (a) }\end{array}$ & 18,67 & $\begin{array}{l}1,44 \mathrm{~d} \\
\text { (a) }\end{array}$ & \\
\hline 20 & 28,00 & $\begin{array}{c}1,52 \mathrm{c} \\
\text { (a) }\end{array}$ & 26,33 & $\begin{array}{c}1,50 \mathrm{c} \\
\text { (a) }\end{array}$ & 28,00 & $\begin{array}{l}1,52 \mathrm{c} \\
\text { (a) }\end{array}$ & $\mathbf{0 , 0 2 7}$ \\
\hline 40 & 76,67 & $\begin{array}{l}1,72 \mathrm{~b} \\
\text { (a) }\end{array}$ & 44,33 & $\begin{array}{l}1,60 \mathrm{~b} \\
\text { (b) }\end{array}$ & 42,00 & $\begin{array}{l}1,59 \mathrm{~b} \\
\text { (b) }\end{array}$ & \\
\hline 80 & 97,33 & $\begin{array}{c}1,77 \mathrm{a} \\
\text { (a) }\end{array}$ & 91,67 & $\begin{array}{c}1,76 \mathrm{a} \\
\text { (a) }\end{array}$ & 95,33 & $\begin{array}{c}1,76 \mathrm{a} \\
\text { (a) }\end{array}$ & \\
\hline BNT 0,05 & & & & 0,036 & & & \\
\hline
\end{tabular}

Berdasarkan Tabel 3, jenis dan kerapatan gulma saling berinteraksi dalam mempengaruhi persentase penutupan gulma 9 MST. Asystasia gangetica, Cyperus rotundus, dan Rottboelia exaltata menghasilkan persentase penutupan yang samapada kerapatan 10, 20, dan $80 \mathrm{gulma} / \mathrm{m}^{2}$. Asystasia gangetica menghasilkan persentase penutupan gulma tertinggi pada kerapatan $40 \mathrm{gulma} / \mathrm{m}^{2}$. Hal ini diduga karena Asystasia gangetica tumbuh lebih tahan terhadap naungan, pada umur 9 MST kanopi tanaman sorgum sudah menutup sehingga cahaya matahari yang masuk sedikit dan menutupi tumbuhan yang tumbuh dibawahnya. Hal ini sejalan dengan Tanasale (2010) yang menyatakan bahwa jenis gulma Asystasia gangetica merupakan gulma yang tahan dan tumbuh subur di lahan naungan sehingga pertumbuhannya lebih cepat.

Berdasarkan Tabel 4, jenis dan kerapatan gulma saling berinteraksi dalam mempengaruhi bobot kering total gulma. Rottboelia exaltata menghasilkan bobot kering total tertinggi dibandingkan dengan Asystasia gangetica dan Cyperus rotundus pada kerapatan 10, 20, dan $80 \mathrm{gulma} / \mathrm{m}^{2}$. Rottboelia exaltata pada kerapatan 10, 20, dan $40 \mathrm{gulma} / \mathrm{m}^{2}$ menghasilkan bobot kering total yang sama. Hal ini diduga ada persaingan antar gulma itu sendiri. Kerapatan 80 gulma $/ \mathrm{m}^{2}$ pada ketiga jenis gulma menghasilkan bobot kering total gulma tertinggi. Hal ini sependapat dengan Gardner et al. (1991) yang dikutip dalam Mursito dan Kawiji (2001) menyatakan bahwa kerapatan tanaman berkaitan dengan hasil tanaman, kerapatan yang tinggi akan meningkatkan jumlah tanaman sehingga akan diikuti dengan meningkatnya bobot kering total tanaman.

\section{Pertumbuhan Tanaman}

Jenis dan kerapatan gulma mempengaruhi tinggi tanaman sorgum pada umur 3 MST (Tabel 5). Tinggi tanaman sorgum umur 3 MST pada gulma Rottboelia exaltata lebih rendah dibandingkan gulma lainnya. Tinggi tanaman umur 3 MST pada kerapatan 80 gulma $/ \mathrm{m}^{2}$ yang paling rendah. Jenis dan kerapatan gulma tidak mempengaruhi tinggi tanaman pada umur 6 MST. Tinggi tanaman umur 9 MST tertinggi pada 
Dita Anggeraini dkk: Pengaruh Jenis dan Tingkat Kerapatan Gulma Terhadap Pertumbuhan dan Produksi ...

kerapatan 20 dan 80 gulma $/ \mathrm{m}^{2}$. Hal ini diduga terjadi etiolasi pada tanaman karena adanya persaingan cahaya matahari yang mengakibatkan meningkatnya tinggi tanaman. Hal ini sependapat dengan Harjadi (1993) yang dikutip dalam Mamilianti (2000), bahwa pada intensitas cahaya yang rendah tidak terjadi pengaliran auksin ke bagian tanaman yang lain yang tidak terkena cahaya matahari sehingga auksin menumpuk dan mendorong tingginya tanaman.

Tabel 4. Pengaruh jenis dan tingkat kerapatan gulma pada bobot kering total gulma

\begin{tabular}{|c|c|c|c|c|c|c|c|}
\hline \multirow{3}{*}{$\begin{array}{l}\text { Kerapatan } \\
\text { gulma } / \mathrm{m}^{2}\end{array}$} & \multicolumn{6}{|c|}{ Jenis gulma } & \multirow{3}{*}{$\begin{array}{l}\text { BNT } \\
0,05\end{array}$} \\
\hline & \multicolumn{2}{|c|}{ Asystasia gangetica } & \multicolumn{2}{|c|}{ Cyperus rotundus } & \multicolumn{2}{|c|}{ Rottboelia exaltata } & \\
\hline & Asli & $\begin{array}{c}\text { Transformasi } \\
\sqrt{ } \sqrt{ } \sqrt{ }(x+0,5)\end{array}$ & Asli & $\begin{array}{c}\text { Transformasi } \\
\sqrt{ } \sqrt{ } \sqrt{ }(x+0,5)\end{array}$ & Asli & $\begin{array}{l}\text { Transformasi } \\
\sqrt{ } \sqrt{ } \sqrt{ }(x+0,5)\end{array}$ & \\
\hline & \multicolumn{6}{|c|}{ 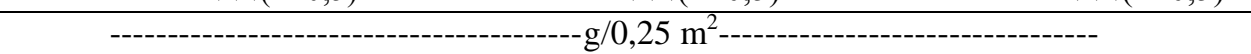 } & \multirow{7}{*}{$\mathbf{0 , 1 2 0}$} \\
\hline 0 & 0.00 & $\begin{array}{l}0.92 \mathrm{c} \\
\text { (a) }\end{array}$ & 0.00 & $\begin{array}{c}0.92 \mathrm{c} \\
\text { (a) }\end{array}$ & 0.00 & $\begin{array}{c}0.92 \mathrm{c} \\
\text { (a) }\end{array}$ & \\
\hline 10 & 14.72 & $\begin{array}{l}1.41 \mathrm{~b} \\
\text { (b) }\end{array}$ & 9.48 & $\begin{array}{c}1.33 \mathrm{~b} \\
\text { (b) }\end{array}$ & 50.20 & $\begin{array}{c}1.63 \mathrm{~b} \\
\text { (a) }\end{array}$ & \\
\hline 20 & 20.70 & $\begin{array}{l}1.46 \mathrm{~b} \\
\text { (b) }\end{array}$ & 16.89 & $\begin{array}{l}1.43 \mathrm{~b} \\
\text { (b) }\end{array}$ & 50.95 & $\begin{array}{l}1.64 \mathrm{~b} \\
\text { (a) }\end{array}$ & \\
\hline 40 & 42.18 & $\begin{array}{c}1.60 \mathrm{ab} \\
\text { (a) }\end{array}$ & 37.35 & $\begin{array}{c}1.57 \mathrm{ab} \\
\text { (a) }\end{array}$ & 56.19 & $\begin{array}{l}1.66 \mathrm{~b} \\
\text { (a) }\end{array}$ & \\
\hline 80 & 45.96 & $\begin{array}{c}1.62 \mathrm{a} \\
\text { (b) }\end{array}$ & 50.64 & $\begin{array}{c}1.64 \mathrm{a} \\
\text { (b) }\end{array}$ & 141.50 & $\begin{array}{c}1.86 \mathrm{a} \\
\text { (a) }\end{array}$ & \\
\hline BNT 0,05 & & & & $\mathbf{0 , 1 3 8}$ & & & \\
\hline
\end{tabular}

Keterangan: Angka yang diikuti oleh huruf yang sama tidak berbeda nyata berdasarkan uji BNT pada taraf 5\% engan tanda kurung untuk jenis gulma dan tanpa tanda kurung untuk kerapatan gulma.

Tabel 5. Pengaruh jenis dan tingkat kerapatan gulma pada tinggi tanaman sorgum pada umur 3, 6, dan 9 MST

\begin{tabular}{|c|c|c|c|}
\hline \multirow{2}{*}{ Perlakuan } & \multicolumn{3}{|c|}{ Tinggi tanaman } \\
\hline & $3 \mathrm{MST}$ & $6 \mathrm{MST}$ & $9 \mathrm{MST}$ \\
\hline \multicolumn{4}{|l|}{ Jenis gulma } \\
\hline Asystasia gangetica & $58,71 \mathrm{ab}$ & $190,98 \mathrm{a}$ & 269,73 a \\
\hline Cyperus rotundus & 58,65 a & $193,30 \mathrm{a}$ & $268,75 \mathrm{a}$ \\
\hline Rottboelia exaltata & $54,71 \mathrm{~b}$ & $188,17 \mathrm{a}$ & $269,47 \mathrm{a}$ \\
\hline $\mathrm{BNT}_{0,05}$ & 3,77 & 6,09 & 7,68 \\
\hline \multicolumn{4}{|l|}{ Kerapatan gulma/m² } \\
\hline 0 & $60,95 \mathrm{a}$ & $190,83 \mathrm{a}$ & $262,14 \mathrm{~b}$ \\
\hline 10 & $55,07 \mathrm{bc}$ & $189,39 \mathrm{a}$ & $268,97 \mathrm{ab}$ \\
\hline 20 & $56,73 \mathrm{abc}$ & $193,83 \mathrm{a}$ & $276,47 \mathrm{a}$ \\
\hline 40 & $59,13 \mathrm{ab}$ & $191,92 \mathrm{a}$ & $260,72 \mathrm{~b}$ \\
\hline 80 & $54,25 \mathrm{c}$ & $188,11 \mathrm{a}$ & $278,28 \mathrm{a}$ \\
\hline $\mathrm{BNT}_{0,05}$ & 4,87 & 7,87 & 9,91 \\
\hline
\end{tabular}

Keterangan: Angka yang diikuti oleh huruf yang sama tidak berbeda nyata berdasarkan uji BNT pada taraf 5\%.

Berdasarkan Tabel 6, jumlah daun tanaman sorgum umur 3, 6, dan 9 MST tidak dipengaruhi oleh jenis gulma. Namun jumlah daun umur 6 MST dipengaruhi oleh kerapatan gulma. Jumlah daun kerapatan 80 gulma $/ \mathrm{m}^{2}$ paling rendah dibandingkan dengan kerapatan lainnya walaupun tidak berbeda nyata. Hal ini diduga kurangnya unsur hara bagi tanaman. Menurut Harjadi (1980) dalam Mursito dan Kawiji (2001) 


\section{Jurnal Penelitian Pertanian Terapan}

menyatakan bahwa ketersediaan unsur hara yang cukup memungkinkan proses fotosintesis optimum dan asimilat yang dihasilkan dapat digunakan sebagai cadangan makanan, karena cadangan makanan dalam jaringan lebih banyak sehingga terbentuknya daun yang dihasilkan lebih banyak pula.

Tabel 6. Pengaruh jenis dan tingkat kerapatan gulma pada jumlah daun sorgum pada umur 3, 6, dan 9 MST.

\begin{tabular}{|c|c|c|c|c|c|}
\hline \multirow{3}{*}{ Perlakuan } & \multicolumn{5}{|c|}{ Jumlah daun } \\
\hline & \multicolumn{2}{|r|}{$3 \mathrm{MST}$} & $6 \mathrm{MST}$ & \multicolumn{2}{|c|}{$9 \mathrm{MST}$} \\
\hline & Asli & $\begin{array}{l}\text { Transformasi } \\
\sqrt{\sqrt{ }(x+0,5)}\end{array}$ & & Asli & $\begin{array}{l}\text { Transformasi } \\
\sqrt{\sqrt{ }(x+0,5)}\end{array}$ \\
\hline Jenis Gulma & \multicolumn{5}{|c|}{ 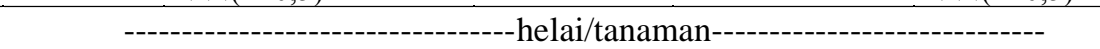 } \\
\hline Asystasia gangetica & 5,06 & $1,23 \mathrm{a}$ & 9,85 a & 15,45 & $1,41 \mathrm{a}$ \\
\hline Cyperus rotundus & 5,30 & $1,24 \mathrm{a}$ & $10,08 \mathrm{a}$ & 15,98 & $1,41 \mathrm{a}$ \\
\hline Rottboelia exaltata & 5,33 & $1,24 \mathrm{a}$ & $9,95 \mathrm{a}$ & 15,81 & $1,41 \mathrm{a}$ \\
\hline $\mathrm{BNT}_{0,05}$ & & 9,7 & 0,68 & & 6,91 \\
\hline \multicolumn{6}{|l|}{ Kerapatan gulma $/ \mathrm{m}^{2}$} \\
\hline 0 & 5,38 & $1,24 \mathrm{a}$ & $10,55 \mathrm{a}$ & 16,00 & $1,41 \mathrm{a}$ \\
\hline 10 & 5,19 & $1,24 \mathrm{a}$ & $10,02 \mathrm{ab}$ & 15,69 & $1,41 \mathrm{a}$ \\
\hline 20 & 5,19 & $1,24 \mathrm{a}$ & $10,05 \mathrm{ab}$ & 15,72 & $1,41 \mathrm{a}$ \\
\hline 40 & 5,38 & $1,24 \mathrm{a}$ & $9,77 \mathrm{ab}$ & 15,69 & $1,41 \mathrm{a}$ \\
\hline 80 & 5,00 & $1,23 \mathrm{a}$ & $9,38 \mathrm{~b}$ & 15,63 & $1,41 \mathrm{a}$ \\
\hline $\mathrm{BNT}_{0,05}$ & & 0,01 & $\mathbf{0 , 8 8}$ & & 8,92 \\
\hline
\end{tabular}

Keterangan: Angka yang diikuti oleh huruf yang sama tidak berbeda nyata berdasarkan uji BNT taraf 5\%.

Diameter batang tanaman sorgum pada 3 MST dipengaruhi oleh jenis gulma, namun tidak mempengaruhi diameter batang pada umur 6 dan 9 MST (Tabel 7). Hal ini diduga karena pada umur 3 MST tanaman belum cukup mampu bersaing dengan gulma. Diameter batang pada gulma Cyperus rotundus tertinggi, sedangkan diameter batang pada Asystasia gangetica tidak berbeda dengan Rottbelia exaltata. Menurut Lingga dan Marsono (2000) yang dikutip dalam Hutagalung, Siagian, dan Silitonga (2013) yang menyatakan bahwa unsur hara Nitrogen merupakan bahan yang essensial untuk pembelahan dan pembesaran sel yang dapat mempengaruhi besar diameter batang tanaman. Kerapatan 80 gulma $/ \mathrm{m}^{2}$ pada 3, 6, dan 9 MST yang paling rendah dibandingkan dengan kerapatan lainnya. Menurut Dalimoenthe (1995) dalam Widayat (2002) bahwa semakin tinggi kerapatan gulma maka penekanan gulma terhadap pertumbuhan tanaman pokok semakin tinggi.

Tabel 7. Pengaruh jenis dan tingkat kerapatan gulma pada diameter batang sorgum pada umur 3, 6, dan 9 MST.

\begin{tabular}{|c|c|c|c|}
\hline \multirow{2}{*}{ Perlakuan } & \multicolumn{3}{|c|}{ Diameter batang } \\
\hline & $3 \mathrm{MST}$ & $6 \mathrm{MST}$ & 9 MST \\
\hline Jenis gulma & \multicolumn{3}{|c|}{-------------------------cm------------------------- } \\
\hline Asystasia gangetica & $0,65 \mathrm{ab}$ & $2,10 \mathrm{a}$ & $2,05 \mathrm{a}$ \\
\hline Cyperus rotundus & $0,69 \mathrm{a}$ & $2,08 \mathrm{a}$ & $2,06 \mathrm{a}$ \\
\hline Rottboelia exaltata & $0,59 \mathrm{~b}$ & $2,06 \mathrm{a}$ & $1,96 \mathrm{a}$ \\
\hline $\mathrm{BNT}_{0,05}$ & $\mathbf{0 , 0 7}$ & $\mathbf{0 , 1 0}$ & $\mathbf{0 , 1 2}$ \\
\hline \multicolumn{4}{|l|}{ Kerapatan gulma $/ \mathrm{m}^{2}$} \\
\hline 0 & $0,70 \mathrm{ab}$ & $2,26 \mathrm{a}$ & $2,11 \mathrm{a}$ \\
\hline 10 & $0,62 \mathrm{bc}$ & $2,09 \mathrm{bc}$ & $2,11 \mathrm{a}$ \\
\hline 20 & $0,61 \mathrm{bc}$ & $2,00 \mathrm{~cd}$ & $1,96 \mathrm{ab}$ \\
\hline 40 & $0,72 \mathrm{a}$ & $2,16 \mathrm{ab}$ & $2,08 \mathrm{a}$ \\
\hline 80 & $0,57 \mathrm{c}$ & $1,89 \mathrm{~d}$ & $1,86 \mathrm{~b}$ \\
\hline $\mathrm{BNT}_{0,05}$ & 0,09 & 0,13 & 0,16 \\
\hline
\end{tabular}

Keterangan: Angka yang diikuti oleh huruf yang sama tidak berbeda nyata berdasarkan uji BNT pada taraf $5 \%$. 
Dita Anggeraini dkk: Pengaruh Jenis dan Tingkat Kerapatan Gulma Terhadap Pertumbuhan dan Produksi ...

\section{Komponen Hasil}

Hasil penelitian terhadap komponen hasil menunjukkan bahwa bobot 100 butir KA 14\%, bobot basah brangkasan dipengaruhi oleh jenis dan kerapatan gulma. Bobot kering brangkasan hanya dipengaruhi oleh jenis gulma, sedangkan panjang malai, bobot biji sorgum per malai dipengaruhi oleh kerapatan gulma (Tabel 8). Kerapatan 80 gulma $/ \mathrm{m}^{2}$ menurunkan bobot 100 butir, bobot biji sampel, dan bobot brangkasan basah tanaman. Menurut Safitri (2010) adanya penurunan hasil disebabkan oleh kerapatan yang tinggi, meningkatnya persaingan antara tanaman dan gulma dalam memperoleh hara, air dan cahaya matahari. Hal ini didukung oleh Sastroutomo (1990) semakin tinggi kerapatan gulma, semakin tinggi agresifitasnya akibatnya semakin tinggi kerapatan gulma disekitar tanaman menurunkan hasil tanaman yang semakin tinggi.

Tabel 8. Pengaruh jenis dan tingkat kerapatan gulma pada panjang malai, bobot 10 butir, bobot biji sorgum, bobot brangkasan basah, dan kering tanaman sorgum

\begin{tabular}{|c|c|c|c|c|c|}
\hline \multirow[t]{2}{*}{ Perlakuan } & \multirow{2}{*}{$\begin{array}{l}\text { Panjang } \\
\text { malai }\end{array}$} & \multirow{2}{*}{$\begin{array}{l}\text { Bobot } 100 \text { butir } \\
\text { pada KA } 14 \%\end{array}$} & \multirow{2}{*}{$\begin{array}{c}\text { Bobot Biji } \\
\text { Sorgum/4 sampel }\end{array}$} & \multicolumn{2}{|c|}{$\begin{array}{l}\text { Bobot Brangkasan } \\
\text { Tanaman / } 2 \text { sampel }\end{array}$} \\
\hline & & & & Basah & Kering \\
\hline Jenis Gulma & $\mathrm{cm}$ & -- & --g------------------- & & \\
\hline Asystasia gangetica & $18,17 \mathrm{a}$ & $4,63 \mathrm{~b}$ & $366,77 \mathrm{a}$ & $1772,7 \mathrm{~b}$ & $198,26 \mathrm{~b}$ \\
\hline Cyperus rotundus & $18,57 \mathrm{a}$ & $4,78 \mathrm{a}$ & $393,55 \mathrm{a}$ & $2057,0 \mathrm{a}$ & 223,96 a \\
\hline Rottboelia exaltata & $18,25 \mathrm{a}$ & $4,62 \mathrm{~b}$ & $375,93 \mathrm{a}$ & $1806,0 \mathrm{~b}$ & $227,44 \mathrm{a}$ \\
\hline BNT 0,05 & $\mathbf{0 , 1 2}$ & 0,12 & 38,91 & 204,86 & 24,61 \\
\hline Populasi gulma $/ \mathrm{m}^{2}$ & & & & & \\
\hline 0 & $18,80 \mathrm{a}$ & $4,79 \mathrm{a}$ & $410,82 \mathrm{a}$ & $1781,1 \mathrm{ab}$ & $216,61 \mathrm{a}$ \\
\hline 10 & $18,28 \mathrm{ab}$ & $4,67 \mathrm{ab}$ & $378,74 \mathrm{a}$ & $2044,4 \mathrm{a}$ & $218,72 \mathrm{a}$ \\
\hline 20 & $18,54 \mathrm{ab}$ & $4,66 \mathrm{ab}$ & $390,61 \mathrm{a}$ & $2000,0 \mathrm{ab}$ & $203,07 \mathrm{a}$ \\
\hline 40 & $17,94 \mathrm{~b}$ & $4,68 \mathrm{ab}$ & $385,27 \mathrm{a}$ & $1893,3 \mathrm{ab}$ & $233,09 \mathrm{a}$ \\
\hline 80 & $18,10 \mathrm{ab}$ & $4,58 \mathrm{~b}$ & $328,29 \mathrm{~b}$ & $1673,9 \mathrm{~b}$ & $211,28 \mathrm{a}$ \\
\hline BNT 0,05 & $\mathbf{0 , 1 6}$ & $\mathbf{0 , 1 5}$ & 50,24 & 264,48 & 31,77 \\
\hline
\end{tabular}

Keterangan: Angka yang diikuti oleh huruf yang sama tidak berbeda nyata berdasarkan uji BNT pada taraf $5 \%$.

Produksi sorgum tidak dipengaruhi oleh jenis dan kerapatan gulma (Tabel 9). Besarnya kehilangan hasil panen tanaman pangan akibat kompetisi sangat erat kaitannya dengan jenis tanaman budidaya dan gulma yang menyebabkan kerugian pada tanaman. Pengaruh kemampuan kompetisi tanaman budidaya terhadap suatu jenis gulma berbeda satu dengan yang lainnya. Menurut (Zimdahl, 1980 dalam Widayat, 2002) bahwa kehilangan hasil produksi tanaman berkaitan dengan bentuk morfologi gulma dan tanaman itu sendiri serta besarnya kompetisi tergantung pada lamanya kompetisi dan daya kompetisi antara tanaman dengan gulma.

Tabel 9. Pengaruh jenis dan tingkat kerapatan gulma pada produksi sorgum dengan KA $14 \%$.

\begin{tabular}{lcc}
\hline \multirow{2}{*}{ Perlakuan } & \multicolumn{2}{c}{ Produksi sorgum } \\
\cline { 2 - 3 } Jenis gulma & $\mathrm{kg} / 2,25 \mathrm{~m}^{2}$ & ton/hektar \\
\hline Asystasia gangetica & $\mathrm{kg}$ & Ton \\
Cyperus rotundus & $0,96 \mathrm{a}$ & $4,18 \mathrm{a}$ \\
Rottboelia exaltata & $0,99 \mathrm{a}$ & $4,23 \mathrm{a}$ \\
\hline BNT 0,05 & $0,93 \mathrm{a}$ & $4,01 \mathrm{a}$ \\
\hline Kerapatan gulma $/ \mathrm{m}^{2}$ & $\mathbf{0 , 0 9}$ & $\mathbf{0 , 4 0}$ \\
\hline 0 & & 4,23 a \\
10 & $0,98 \mathrm{a}$ & $4,18 \mathrm{a}$ \\
20 & $0,97 \mathrm{a}$ & $4,15 \mathrm{a}$ \\
40 & $0,96 \mathrm{a}$ & 3,98 a \\
80 & $0,93 \mathrm{a}$ & 4,16 a \\
\hline BNT 0,05 & 0,96 a & $\mathbf{0 , 5 2}$ \\
\hline Keterangan: Angka yang diikuti oleh huruf yang sama tidak berbeda nyata berdasarkan uji BNT pada taraf 5\%.
\end{tabular}




\section{KESIMPULAN}

1. Jenis gulma mempengaruhi pertumbuhan dan komponen hasil yang meliputi tinggi tanaman dan diameter batang 3 MST, bobot 100 butir pada KA14\%, serta bobot basah dan kering brangkasan,

2. Kerapatan 80 gulma/m $\mathrm{m}^{2}$ mempengaruhi tinggi tanaman 3 dan 9 MST, jumlah daun 6 MST, diameter batang 3, 6, dan 9 MST, bobot 100 butir pada KA 14\%, bobot biji sorgum, dan bobot brangkasan basah tanaman, dan

3. Antara jenis dan kerapatan gulma tidak ada interaksi dalam mempengaruhi pertumbuhan dan produksi tanaman sorgum, namun terdapat interaksi dalam mempengaruhi pertumbuhan gulma.

\section{DAFTAR PUSTAKA}

Hasanuddin, G. Erida, dan Safmaneli. 2012. Pengaruh Persaingan Gulma Synedrella nodiflora L. Gaertn.Pada Berbagai Densitas Terhadap Pertumbuhan Hasil Kedelai.Fakultas Pertanian Universitas Syiah Kuala. Banda Aceh. Jurnal Agrista.Vol.16 (3). Hal 146-152.

Hutagalung, W.J., B. Siagian, dan S.Silitonga.2013. Respon Pertumbuhan Bibit Kakao Pada Media Subsoil Ultisol dengan Pemberian Pupuk Hayatibiokom dan Kompos. Fakultas Pertanian USU Medan.Jurnal Online Agroekoteknologi Vol.1 (2) Hal 327-326.

Lindung.2011. Kajian Pemupukan Fosfat terhadap Pertumbuhan dan Hasil Tanaman Sorgum (Sorghum Bicolor L.) Balai Pelatihan Pertanian Jambi. Jambi.32 hal.

Mamilianti, W. 2000.Pengaruh Jarak Tanam dan Pemberian Dosis Pupuk Kandang Terhadap Pertumbuhan dan Hasil Tanaman Kanola (Brassica Campestris X Brassica Napus). Jurnal Fakultas Pertanian Universitas Yudharta Pasuruan. 11 hal.

Moenandir, J. 1993. Pengantar Ilmu dan pengendalian Gulma.Buku Edisi I. PT Raja Grafindo Persada. Jakarta.

Mursito, D., dan Kawiji. 2001. Pengaruh Kerapatan Tanam danKedalaman Olah Tanah Terhadap. Hasil Umbi Lobak (Raphanus Sativus L.). Jurnal Fakultas Pertanian UNS. 6 hal.

Pasau, P., P.Yudono, A.Syukur. 2008. Pergeseran Komposisi Gulma Pada Perbedaan Proporsi Populasi Jagung dan Kacang Tanah dalam Tumpangsari Pada Regosol Sleman. Fakultas Pertanian UGM. Yogyakarta.Jurnal Ilmu Pertanian. Vol. 16 (2). Hal. 60 - 78.

Safitri,R. 2010. Pengaruh Jarak Tanam dan Dosis Pupuk Kandang Ayam Terhadap Pertumbuhan dan Hasil Tanaman Sorgum Manis (Sorghum Bicolor, L.Moench).Jurusan Budidaya Pertanian Fakultas Pertanian Universitas Andalas Jerami Volume 3(2). Hal.107-119.

Sastroutomo, S.S. 1990. Ekologi Gulma. Gramedia Pustaka Utama. Jakarta. 217 hal. Sembodo, D.R.J. 2010. Gulma dan Pengolahannya. Penerbit Graha Ilmu. Edisi Pertama.Yogyakarta.

Tanasale, V. 2010. Komunitas Gulma PadaPertanaman Gandaria Belum Menghasilkan dan Menghasilkan Pada Ketinggian Tempat yang Berbeda.UGM.Yogyakarta. Hal. 134-142

Widayat, D. 2002. Kemampuan Berkompetisi Kedelai (Glycine Max) Kacang Tanah (Arachis Hypogaea) dan Kacang Hijau (Vigna Radiata) Terhadap Teki (Cyperus Rotundus). Jurnal Bionatura, Fakultas Pertanian Universitas Padjadjaran. Vol.4(2). Hal. 118 - 128. 